\title{
The Absence Consequences of Overtime in the Transit Industry
}

Yoram Shiftan, Technion, Israel Institute of Technology Nigel H. M. Wilson, Massachusetts Institute of Technology.

\begin{abstract}
The transit industry relies on overtime to fill in for worker absence or to cover unexpected extra work. The purpose of this article is to study the absence consequences of overtime in the transit industry through a disaggregate model of absence. The model was estimated with panel data of transit operators to test the hypothesis that widespread availability of overtime may induce absence. This might occur for two reasons. Some employees may be more likely to be absent after reaching a threshold pay amount for a period, and this level will be reached after fewer hours on the job if overtime work is readily available. Other employees may be absent more because of the increased stress and fatigue associated with regularly working long hours including overtime. The results suggest that absence is more a habit than the result of a decision process based on past overtime worked.
\end{abstract}

\section{Introduction}

The transit industry relies on overtime to fill in for worker absence or to cover unexpected extra work. The importance of service reliability and the uncertainty about both the workforce available and the amount of work to be performed at a given time in the transit industry leads to the employment of more workers than those actually scheduled for work. Too large a workforce will result in low productivity, since some employees who do not have any useful work to perform must still be paid. Reducing the workforce size will require 
more overtime. Since it is common in the transit industry to provide substantial fringe benefits for employees but only small marginal benefits for working overtime (beyond the typical pay premium), it is not unusual for the total cost per hour of labor produced by an employee working overtime to be similar to that for an employee working regular time. This situation may lead to a policy of relying heavily on overtime to fill in for absent employees and to cover extra work requirements.

There are two reasons why this naive "cost-minimizing" solution might be inappropriate. First, frequently employees have the right to decline overtime work if they so choose, and the greater the reliance on overtime, the larger the number of situations in which no employees will be available and willing to work overtime, thus potentially significantly affecting service reliability. Second, if large amounts of overtime are worked, there may be an increase in levels of absence among the workforce. This might occur for two reasons. Some employees may be more likely to be absent after reaching a threshold pay amount for a period, and this level will be reached after fewer hours on the job if overtime work is readily available. Other employees may be absent more because of the increased stress and fatigue associated with regularly working long hours including overtime. In many properties, straight runs can be as long as 9 or 10 hours. The union contract usually requires that the longest duties go to regular operators who can also work overtime. This can result in operators working up to 13 or 14 hours per day and receiving up to 17 hours of equivalent straight-time pay. This has resulted in a great deal of stress on the operator in some properties.

Several papers have explored the general relationships between absence and overtime, some finding positive correlation between these two variables (Martin 1971; Gowler 1969), with others finding no such relationship (Buck and Shimmin 1959; Flanagan et al. 1974). Within the transit industry few studies found positive relationships between absence and overtime work including Perry (1983), Leahy, Sprague, and Schlegel (1979), Brown (1981) (as cited by Perry 1983), and Perin (1984); one study (Smith et al. 1980) found no such relationships. Considering that all these studies used either aggregate or weak mea- 
sures of absence or overtime, or small samples, further study is required to resolve the relationship between overtime availability and absence.

This article examines the absence consequences of overtime in the transit industry. If reliance on overtime creates more absence, then the direct cost of the employee working overtime will be less than the full cost of the overtime. Understanding the full cost of overtime is essential to the decision on workforce sizing as shown by strategic workforce planning models (Koutsopoulos and Wilson 1987; Hickman et al.1988; and Shiftan and Wilson 1994). This issue is of special interest today because many industries are aggressively downsizing their workforce.

This article presents a case study based on the Massachusetts Bay Transportation Authority (MBTA) to study this problem. The cost structure in which an hour of overtime costs the agency less than an hour of an extra operator is true for the MBTA because the high cost of fringe benefits that apply to employees working regular time outweighs the 50 percent pay premium for overtime work. The researchers test the hypothesis that widespread overtime availability may induce absence versus the alternative hypothesis that absence is more a result of individual characteristics through a disaggregate model of employee absence. The next section presents the development of a theoretical framework for exploring the relationship between overtime and absence, assuming absence results from a decision process using the income-leisure trade-off model.

\section{The Income-Leisure Trade-off Model}

Subjective cost/benefit or income/leisure evaluation by the employee is known as the income-leisure trade-off in workforce participation. Under this theory, the employee evaluates the economic and social benefits of work attendance versus leisure time and acts accordingly. Holding work schedule flexibility constant, the researchers analyze the work attendance decision within the conventional labor-leisure choice framework. Workers maximize a utility function containing consumption $(\mathrm{X})$ and leisure $(\mathrm{L})$ :

$$
\mathrm{U}=\mathrm{U}(\mathrm{X}, \mathrm{L})
$$


The worker faces two constraints, a time constraint and a budget constraint. Including both absence and overtime as decision variables, the time constraint can be written as:

$$
t-t^{c}-t^{t}-t^{0}=0
$$

where:

$t$ represents the total time in the period under consideration,

$t^{c}$ is the contracted number of work hours,

$t^{t}$ is leisure hours not including absence hours $\left(L=t^{t}+t^{2}\right.$ where $t^{a}$ is absence hours), and

$t^{0}$ is the amount of overtime worked. The budget constraint is:

$$
R+w\left(t^{\mathrm{c}}-t^{\mathrm{a}}\right)+w^{*} t^{\mathrm{o}}-D\left(t^{\mathrm{a}}\right)-\mathrm{X}=0
$$

where:

$R$ is income from sources other than work,

$w$ is the wage rate,

$w^{*}$ is the overtime pay rate, and

$D$ is a lump sum penalty for absence.

In practice, this penalty will be observed as a decreased probability of receiving a promotion or merit wage increase and an increased likelihood of being suspended or dismissed. The assumption is that the worker is not paid for absence hours. Substitution of Equations 2 and 3 into Equation 1 and differentiation with respect to $t$ and $t$ produce the following first-order equilibrium conditions:

$$
\begin{gathered}
\mathrm{U}_{\mathrm{L}}-(w+D) \mathrm{U}_{\mathrm{X}}=0 \\
-\mathrm{U}_{\mathrm{L}}+\mathrm{U}_{\mathrm{X}} w^{*}=0
\end{gathered}
$$

where:

$U_{\mathrm{k}}$ indicates the partial derivative of $\mathrm{U}$ with respect to $k=\mathrm{L}, \mathrm{X}$. 
The first condition indicates that a worker will be absent on any given day if the extra leisure is more valuable than the sum of the wages he or she would have earned that day and the associated loss in future earnings. This means that the shadow price of leisure time for absent workers is greater than the contracted wage. The second condition indicates that an employee is willing to work overtime as long as the overtime wage is more valuable than the extra leisure.

If the value of extra leisure is less than the overtime wage but more than the sum of the regular wage and the resultant loss in future earnings, then the employee would be willing both to take absence and to work overtime. The value of leisure may vary from day to day, resulting in employees opting for both overtime and absence over some period.

This analysis suggests that the absence model should include overtime $o$ and the overtime wage rate $w^{*}$ and can be written as:

$$
a=a\left(w, r, f^{c}, D, f, o, w^{*}\right)
$$

where:

$f$ is the schedule flexibility permitted.

The focus of this model is on voluntary absence that is a function of the worker's motivation to attend work, as opposed to involuntary absence that results from inability, rather than unwillingness, to attend work. Voluntary absence may also be a function of involuntary absence in prior periods. Even if the operator has other duties or was injured and had an involuntary absence, he or she still had a break from the routine of the job and the attendant stress and might be less inclined to take a voluntary absence in the following periods.

Overtime and absence over a period together define the individual tradeoff between leisure and income. If the worker has been absent too much in one period, in the sense that he or she ends the period "underemployed," the individual may tend to be absent less in the next period to recoup lost income. If on the other hand, the worker is "overemployed" in one period because of working overtime, he or she may tend to be absent in the following period to gain more leisure. This is consistent with Fichman's (1984) dynamic model of 
attendance, in which absence is one observable consequence of changing the allocation of time and effort from work to nonwork activity, and suggests that absences should be modeled dynamically, by letting the absence in period $t$ be a function of absence and overtime in prior periods. Each individual has his or her own target point in terms of the income-leisure trade-off. Assuming that each individual has a constant target point over time, this unobserved characteristic can be modeled by the individual history of absence and overtime over a relatively long period. In addition, differences in operator characteristics can be captured by operator-specific dummy variables that should be significant if absence is a habit. Finally, temporal variation can be accounted for by seasonal dummy variables that can test, for example, if there are higher absence rates in the summer when leisure time may have a higher value. All these effects and variables in the model can be written as:

$$
a_{\mathrm{tv}}=a\left(w, r, t^{\mathrm{c}}, d, f, o, w^{*}, A a_{\mathrm{i}}, A a_{\mathrm{v}}, O a, a_{\mathrm{t}-1, \mathrm{i}}, a_{\mathrm{t}-1, \mathrm{v}}, o_{\mathrm{t}-1}, a_{\mathrm{t}-2, \mathrm{l}}, a_{\mathrm{t}-2, \mathrm{v}}, o_{\mathrm{t}-2}, \ldots,\right.
$$

$$
\text { oper } \left._{\mathrm{i}}, \ldots, \text { season }_{1}, \text { season }_{2}, \ldots\right)
$$

where:

$a_{\mathrm{t}, \mathrm{v}}=$ voluntary absence in period $t$,

$a_{\mathrm{t}-\mathrm{k}, \mathrm{i}}=$ involuntary absence in period $t-k$,

$A a_{\mathrm{i}}=$ mean amount of past involuntary absence per period,

$A a_{\mathrm{v}}=$ mean amount of past voluntary absence per period,

$O a=$ average overtime over the $n$ periods before $t$,

$A a=$ average absence over the $n$ periods before $t$,

oper $_{\mathrm{i}}=$ dummy variables equal 1 for operator $i$ and 0 for all other operators, season $_{\mathrm{i}}=$ dummy variables equal 1 for season $i$, and 0 for any other season.

\section{The Income-Leisure Theory in the Transit Industry}

Several factors may make the income-leisure theory more significant in the transit industry than in some other industries:

1) Widespread availability of overtime may allow some employees to quickly recoup wages lost to absence, diminishing the economic benefits of regular work attendance. 
2) Scheduling inflexibility reduces the operator's opportunity to take time off when needed or desired. Some operators may then use sick leave as a means to obtain time off.

3)Management's inability to schedule personnel effectively results in an endless cycle in which operators work overtime and then take time off to compensate, resulting in more absence, and thus in more overtime work, etc.

4) The extraboard encourages employee absence because employees are aware that replacements are available for them. This problem may be exacerbated or perpetuated by the common practice of basing the current size of the extraboard on past levels of employee absence.

5) Occupational stress associated with working long and irregular hours may also induce absence. Occupational stress is not included as a separate variable in this model because it is very difficult to measure. However, stress is included in the model implicitly under the assumption that working overtime may increase stress.

\section{The MBTA Case Study}

In this section, the absence model is applied using data from the MBTA. The sample consists of 274 operators from all bus and trolley garages. The data include number of absence hours each day for each operator, the category of each absence, and the weekly payment for overtime worked during a period of one year.

The absences are classified into three groups:

1) voluntary absences (unauthorized absence) which are not paid;

2) involuntary absences (death in the family, industrial accident, military or jury duty, and excused) which are paid; and

3) sick absences which are not paid for the first day of the absence but are paid for any subsequent day.

Sick absences are a separate category because while it includes real sickness that should be considered involuntary, it may also be a way for an operator to take a voluntary absence. Overtime payment is on a daily basis for any time worked above 8 hours. This means that an operator can receive overtime 
compensation without working 40 hours a week and that an operator can both receive overtime compensation and be absent in the same week. The overtime pay rate is 1.5 times the base wage rate, but there are no fringe benefits charged to overtime.

Table 1 summarizes the absence and overtime variables, including the number of zero values for one of the seven MBTA garages. In this dataset, each observation corresponds to an operator weekly record.

\begin{tabular}{|lccc|}
\hline \multicolumn{4}{|c|}{$\begin{array}{c}\text { Table 1 } \\
\text { Summary of Absence and Overtime Data }\end{array}$} \\
\hline & $\stackrel{M}{S}$ & $\underline{S D}$ & $\%$ of observed \\
$(\mathrm{hr} / w k)$ & $(\mathrm{hr} / w k)$ & values $=0$ \\
\hline Absence & & & \\
Voluntary & 0.12 & 1.90 & 99.3 \\
Involuntary & 0.59 & 3.86 & 95.5 \\
Sick & 1.50 & 5.90 & 89.5 \\
Total & 2.20 & 7.27 & 84.9 \\
Overtime & 0.65 & 1.86 & 79.5 \\
\hline
\end{tabular}

As seen from Table 1, the occurrence of voluntary absence is very lowless than 10 percent of all absences. To explore whether some sick absences might be better classified as voluntary absences, Table 2 shows the duration of sick absences for a sample garage.

In light of the very high percentage of one-day sick absences and to model voluntary absences more realistically, the researchers defined new absence variables as follows:

- Short: any voluntary absence plus any single-day sick absence.

- Long: any sick absence that consists of at least two consecutive days. 


\begin{tabular}{|ccc|}
\hline \multicolumn{4}{|c|}{ Table 2} \\
& Frequencies of Sick Absences \\
\hline Days & Frequency & Percent \\
\hline 1 & 279 & 62.3 \\
2 & 55 & 12.3 \\
3 & 26 & 5.8 \\
4 & 48 & 10.7 \\
5 & 40 & 8.9 \\
\hline
\end{tabular}

The assumption is that most long sick absences are genuine and most short sick absences are really voluntary. Clearly, some short absences will really be involuntary, while some long absences may be voluntary, but there is no more reliable way to distinguish between the two. These categories are also consistent with the payment category: Long absences are paid (except the first day) while short ones are not. A model for short absence is consistent with the theoretical model, which assumes that absences are not paid.

In this study, duration rather than frequency was used as the absence measure because it is more consistent with the theoretical model. It is the duration of an absence rather than frequency that determines income. The researchers used a time unit of one week because they do not expect the hypothesized relationships to exist on a daily level, and analyzing longer periods may cause loss of important information. Wages at the MBTA are paid weekly, which also suggests that a week is an appropriate period for analysis, as this is the shortest period of perceived income for the operator. The model was estimated using the tobit model developed for censored data (Maddala 1983), as in this case clearly no employee can be absent a negative number of hours.

\section{Model Estimation Results}

The researchers estimated separate models for each garage because, even though absence and overtime policies are the same across all garages, their 
enforcement and application may vary. Classifying absence into the different categories may vary, as may the relationship between supervisors and operators.

Three different time-based explanatory variables were used for each absence category as well as for overtime. The definitions below are for the long variable but similar definitions hold for the short, the involuntary (invol), and overtime (ot) variables:

- Long_l is the amount of long absence in the immediately preceding week.

- Long_234 is the average long absence during preceding weeks 2 through 4.

- Long_past is the average long absence during preceding weeks 5 through 16.

- Winter, Spring, and Summer are seasonal dummy variables.

- Oper_i,i=1,2, . n are operator-specific dummy variables.

Table 3 shows the estimation results for each garage including the dummy variables for the first 16 operators in each garage, which are representative of the remaining results.

The main conclusions from the estimation are:

- Most of the explanatory power is due to the operator-specific dummy variables, for which virtually all coefficients were significant (only 9 out of the 274 dummy operator coefficients were not significant) with $t$-statistics between -1.9 and -5.5 . To test the hypotheses that the constant is not generic, the researchers ran a nested hypothesis test comparing this model to a restricted model. The results showed that for all garages the test statistic (with values in the range of 64-100) was larger than the chi square at 1 percent significance (with values between 60 and 63) and therefore the null hypothesis that the operator-specific dummy coefficients are equal can be rejected.

- The lagged overtime variables are all insignificant and most are negative, suggesting that those who tend to work overtime tend not to be absent.

- Short_l always has a positive coefficient which is generally significant. This is because some short absences in any week are continuations of absence in the preceding week. The long_l variable also has a significant positive coefficient for the same reason. 


\begin{tabular}{|c|c|c|c|c|c|c|c|}
\hline \multicolumn{8}{|c|}{$\begin{array}{c}\text { Table } 3 \\
\text { The Short Absence Model }\end{array}$} \\
\hline & $\begin{array}{c}\text { Garage } \\
122\end{array}$ & $\begin{array}{c}\text { Garage } \\
123\end{array}$ & $\begin{array}{c}\text { Garage } \\
125\end{array}$ & $\begin{array}{c}\text { Garage } \\
126\end{array}$ & $\begin{array}{c}\text { Garage } \\
128\end{array}$ & $\begin{array}{c}\text { Garage } \\
129\end{array}$ & $\begin{array}{c}\text { Garage } \\
132\end{array}$ \\
\hline short[-1] & $\begin{array}{r}0.689 \\
(4.21) \\
\end{array}$ & $\begin{array}{r}0.610 \\
(4.48) \\
\end{array}$ & $\begin{array}{r}0.331 \\
(1.54) \\
\end{array}$ & $\begin{array}{l}0.475 \\
(2.77) \\
\end{array}$ & $\begin{array}{r}0.787 \\
(5.66) \\
\end{array}$ & $\begin{array}{c}0.408 \\
(2.85) \\
\end{array}$ & $\begin{array}{r}0.707 \\
(4.26) \\
\end{array}$ \\
\hline short_234 & $\begin{array}{r}-1.074 \\
(-2.82) \\
\end{array}$ & $\begin{array}{r}-0.383 \\
(-1.66) \\
\end{array}$ & $\begin{array}{c}-0.454 \\
(-0.90) \\
\end{array}$ & $\begin{array}{c}0.007 \\
(0.03)\end{array}$ & $\begin{array}{r}0.165 \\
(0.84) \\
\end{array}$ & $\begin{array}{r}0.242 \\
(1.10) \\
\end{array}$ & $\begin{array}{r}0.211 \\
(0.96 \\
\end{array}$ \\
\hline short_past & $\begin{array}{c}-4.321 \\
(-3.93) \\
\end{array}$ & $\begin{array}{c}-1.410 \\
(-2.56) \\
\end{array}$ & $\begin{array}{r}-3.202 \\
(-2.55) \\
\end{array}$ & $\begin{array}{c}-1.230 \\
(-2.12) \\
\end{array}$ & $\begin{array}{l}-1.324 \\
(-2.85) \\
\end{array}$ & $\begin{array}{r}-2.458 \\
(-4.12) \\
\end{array}$ & $\begin{array}{r}-0.949 \\
(-2.14) \\
\end{array}$ \\
\hline Long[-1] & $\begin{array}{c}0.154 \\
(1.79) \\
\end{array}$ & $\begin{array}{r}0.446 \\
(5.90) \\
\end{array}$ & $\begin{array}{c}0.461 \\
(3.36) \\
\end{array}$ & $\begin{array}{r}0.475 \\
(5.65) \\
\end{array}$ & $\begin{array}{c}0.323 \\
(3.70) \\
\end{array}$ & $\begin{array}{r}0.336 \\
(3.12) \\
\end{array}$ & $\begin{array}{r}0.149 \\
(1.42) \\
\end{array}$ \\
\hline Long_234 & $\begin{array}{c}-0.093 \\
(-0.70) \\
\end{array}$ & $\begin{array}{c}-0.152 \\
(-1.28) \\
\end{array}$ & $\begin{array}{c}-1.343 \\
(-2.42) \\
\end{array}$ & $\begin{array}{r}0.030 \\
(0.21) \\
\end{array}$ & $\begin{array}{r}-0.239 \\
(-1.63) \\
\end{array}$ & $\begin{array}{r}0.320 \\
(1.99) \\
\end{array}$ & $\begin{array}{r}-0.299 \\
(-1.87) \\
\end{array}$ \\
\hline Long_past & $\begin{array}{c}0.218 \\
(0.80) \\
\end{array}$ & $\begin{array}{c}0.275 \\
(1.36) \\
\end{array}$ & $\begin{array}{r}-2.040 \\
(-2.32) \\
\end{array}$ & $\begin{array}{c}-0.279 \\
(-1.07) \\
\end{array}$ & $\begin{array}{c}0.255 \\
(1.25) \\
\end{array}$ & $\begin{array}{r}-0.212 \\
(-0.94) \\
\end{array}$ & $\begin{array}{r}-0.224 \\
(-1.35) \\
\end{array}$ \\
\hline invol[-1] & $\begin{array}{c}-0.306 \\
(-2.29) \\
\end{array}$ & $\begin{array}{l}0.136 \\
(1.26) \\
\end{array}$ & $\begin{array}{c}0.399 \\
(2.21)\end{array}$ & $\begin{array}{c}-0.012 \\
(-0.07) \\
\end{array}$ & $\begin{array}{r}-0.145 \\
(-0.82)\end{array}$ & $\begin{array}{r}-0.299 \\
(-1.37) \\
\end{array}$ & $\begin{array}{r}-0.222 \\
(-1.89) \\
\end{array}$ \\
\hline invol_234 & $\begin{array}{c}-0.041 \\
(-0.30) \\
\end{array}$ & $\begin{array}{c}-0.242 \\
(-1.68) \\
\end{array}$ & $\begin{array}{r}-0.463 \\
(-1.57) \\
\end{array}$ & $\begin{array}{c}0.088 \\
(0.46) \\
\end{array}$ & $\begin{array}{c}0.149 \\
(0.86) \\
\end{array}$ & $\begin{array}{c}-0.152 \\
(-0.76) \\
\end{array}$ & $\begin{array}{r}-0.081 \\
(-0.62) \\
\end{array}$ \\
\hline invol_past & $\begin{array}{c}0.124 \\
(0.53) \\
\end{array}$ & $\begin{array}{c}-0.239 \\
(-1.43) \\
\end{array}$ & $\begin{array}{r}0.621 \\
(1.63) \\
\end{array}$ & $\begin{array}{c}-0.035 \\
(-0.11) \\
\end{array}$ & $\begin{array}{c}0.298 \\
(1.26) \\
\end{array}$ & $\begin{array}{c}0.315 \\
(1.78) \\
\end{array}$ & $\begin{array}{r}-0.436 \\
(-2.50) \\
\end{array}$ \\
\hline Ot & $\begin{array}{c}-0.010 \\
(-0.94) \\
\end{array}$ & $\begin{array}{c}-0.014 \\
(-1.15) \\
\end{array}$ & $\begin{array}{c}-0.018 \\
(-1.09) \\
\end{array}$ & $\begin{array}{r}-0.005 \\
(-0.43) \\
\end{array}$ & $\begin{array}{c}-0.029 \\
(-1.66) \\
\end{array}$ & $\begin{array}{c}0.012 \\
(1.20) \\
\end{array}$ & $\begin{array}{r}-0.009 \\
(-0.84) \\
\end{array}$ \\
\hline ot [-1] & $\begin{array}{c}-0.014 \\
(-1.29) \\
\end{array}$ & $\begin{array}{c}-0.001 \\
(-0.11) \\
\end{array}$ & $\begin{array}{r}-0.011 \\
(-0.65) \\
\end{array}$ & $\begin{array}{c}0.018 \\
(1.45) \\
\end{array}$ & $\begin{array}{c}-0.003 \\
(-0.16) \\
\end{array}$ & $\begin{array}{c}-0.014 \\
(-1.03) \\
\end{array}$ & $\begin{array}{r}-0.001 \\
(-0.16) \\
\end{array}$ \\
\hline ot_234 & $\begin{array}{c}-0.014 \\
(-0.95) \\
\end{array}$ & $\begin{array}{c}0.009 \\
(0.63) \\
\end{array}$ & $\begin{array}{l}-0.0045 \\
(-0.20)\end{array}$ & $\begin{array}{r}-0.023 \\
(-1.09) \\
\end{array}$ & $\begin{array}{c}-0.045 \\
(-1.64) \\
\end{array}$ & $\begin{array}{c}0.0088 \\
(0.51) \\
\end{array}$ & $\begin{array}{r}0.003 \\
(0.22) \\
\end{array}$ \\
\hline ot_past & $\begin{array}{r}-0.013 \\
(-0.44) \\
\end{array}$ & $\begin{array}{c}-0.042 \\
(-1.55) \\
\end{array}$ & $\begin{array}{l}0.0008 \\
(0.02)\end{array}$ & $\begin{array}{r}-0.047 \\
(-1.19) \\
\end{array}$ & $\begin{array}{c}-0.087 \\
(-1.59) \\
\end{array}$ & $\begin{array}{c}-0.032 \\
(-0.82) \\
\end{array}$ & $\begin{array}{r}0.011 \\
(0.56) \\
\end{array}$ \\
\hline Winter90 & $\begin{array}{c}1.778 \\
(0.96) \\
\end{array}$ & $\begin{array}{c}-2.408 \\
(-1.36) \\
\end{array}$ & $\begin{array}{c}-3.193 \\
(-1.47) \\
\end{array}$ & $\begin{array}{c}-0.538 \\
(-0.30) \\
\end{array}$ & $\begin{array}{c}-2.462 \\
(-1.47) \\
\end{array}$ & $\begin{array}{c}0.316 \\
(0.16) \\
\end{array}$ & $\begin{array}{r}1.150 \\
(0.58) \\
\end{array}$ \\
\hline Spring90 & $\begin{array}{c}1.419 \\
(0.86) \\
\end{array}$ & $\begin{array}{c}-0.567 \\
(-0.38) \\
\end{array}$ & $\begin{array}{c}-0.758 \\
(-0.42) \\
\end{array}$ & $\begin{array}{r}-0.387 \\
(-0.26) \\
\end{array}$ & $\begin{array}{r}-1.981 \\
(-1.40) \\
\end{array}$ & $\begin{array}{c}-0.732 \\
(-0.42) \\
\end{array}$ & $\begin{array}{r}4.565 \\
(2.53) \\
\end{array}$ \\
\hline Summer90 & $\begin{array}{c}5.738 \\
(3.03) \\
\end{array}$ & $\begin{array}{r}-2.015 \\
(-1.24) \\
\end{array}$ & $\begin{array}{c}3.292 \\
(1.74) \\
\end{array}$ & $\begin{array}{r}-0.457 \\
(-0.28) \\
\end{array}$ & $\begin{array}{c}-2.026 \\
(-1.35) \\
\end{array}$ & $\begin{array}{r}-1.223 \\
(-0.63) \\
\end{array}$ & $\begin{array}{c}4.892 \\
(2.54) \\
\end{array}$ \\
\hline Oper 1 & -20.841 & -15.788 & -25.782 & -24.073 & -23.830 & -16.085 & -24.780 \\
\hline
\end{tabular}




\begin{tabular}{|c|c|c|c|c|c|c|c|}
\hline & $(-3.17)$ & $(-4.41)$ & $(-3.80)$ & $(-4.93)$ & $(-4.41)$ & $(-3.96)$ & $(-4.50)$ \\
\hline Oper_2 & $\begin{array}{c}-9.892 \\
(-2.93) \\
\end{array}$ & $\begin{array}{c}-19.352 \\
(-4.80)\end{array}$ & $\begin{array}{r}-22.197 \\
(-4.93) \\
\end{array}$ & $\begin{array}{c}-12.493 \\
(-3.92)\end{array}$ & $\begin{array}{r}-15.469 \\
(-3.94)\end{array}$ & $\begin{array}{r}-12.361 \\
(-3.51)\end{array}$ & $\begin{array}{r}-30.827 \\
(-4.35)\end{array}$ \\
\hline Oper_3 & $\begin{array}{l}-23.776 \\
(-3.75)\end{array}$ & $\begin{array}{r}-9.134 \\
(-2.99) \\
\end{array}$ & $\begin{array}{c}-11.449 \\
(-3.19) \\
\end{array}$ & $\begin{array}{c}-19.005 \\
(-4.38)\end{array}$ & $\begin{array}{c}-24.075 \\
(-4.47)\end{array}$ & $\begin{array}{c}-27.970 \\
(-4.49)\end{array}$ & $\begin{array}{r}-27.583 \\
(-4.81) \\
\end{array}$ \\
\hline Oper_4 & $\begin{array}{c}-12.199 \\
(-3.04) \\
\end{array}$ & $\begin{array}{c}-18.496 \\
(-4.61) \\
\end{array}$ & $\begin{array}{c}-24.791 \\
(-4.84) \\
\end{array}$ & $\begin{array}{r}-15.137 \\
(-4.15) \\
\end{array}$ & $\begin{array}{r}-15.949 \\
(-4.06)\end{array}$ & $\begin{array}{c}-23: 063 \\
(-4.48)\end{array}$ & $\begin{array}{c}-29.624 \\
(-5.08) \\
\end{array}$ \\
\hline Oper_5 & $\begin{array}{c}-16.650 \\
(-4.44)\end{array}$ & $\begin{array}{c}-25.333 \\
(-4.38)\end{array}$ & $\begin{array}{c}-24.460 \\
(-3.63)\end{array}$ & $\begin{array}{c}-24.386 \\
(-4.53)\end{array}$ & $\begin{array}{c}-15.130 \\
(-4.36)\end{array}$ & $\begin{array}{c}-27.732 \\
(-4.86)\end{array}$ & $\begin{array}{c}-30.420 \\
(-4.10)\end{array}$ \\
\hline Oper_6 & $\begin{array}{c}-21.194 \\
(-4.74) \\
\end{array}$ & $\begin{array}{r}-17.057 \\
(-4.33) \\
\end{array}$ & $\begin{array}{c}-21.628 \\
(-4.19) \\
\end{array}$ & $\begin{array}{r}-18.909 \\
(-4.77) \\
\end{array}$ & $\begin{array}{r}-18.233 \\
(-4.68) \\
\end{array}$ & $\begin{array}{c}-21.323 \\
(-4.77) \\
\end{array}$ & $\begin{array}{c}-30.716 \\
(-4.81)\end{array}$ \\
\hline Oper_7 & $\begin{array}{c}-27.895 \\
(-4.79) \\
\end{array}$ & $\begin{array}{c}-14.724 \\
(-4.14) \\
\end{array}$ & $\begin{array}{c}-17.843 \\
(-4.08) \\
\end{array}$ & $\begin{array}{c}-24.953 \\
(-4.63) \\
\end{array}$ & $\begin{array}{c}-9.789 \\
(-3.40) \\
\end{array}$ & $\begin{array}{c}-10.219 \\
(-2.86)\end{array}$ & $\begin{array}{c}-19.518 \\
(-3.72) \\
\end{array}$ \\
\hline Oper_8 & $\begin{array}{c}-12.595 \\
(-2.83)\end{array}$ & $\begin{array}{c}-15.391 \\
(-4.38) \\
\end{array}$ & $\begin{array}{r}-13.467 \\
(-3.09) \\
\end{array}$ & $\begin{array}{c}-11.512 \\
(-2.08)\end{array}$ & $\begin{array}{c}-21.460 \\
(-4.78)\end{array}$ & $\begin{array}{c}-17.053 \\
(-3.73) \\
\end{array}$ & $\begin{array}{c}-21.738 \\
(-5.41)\end{array}$ \\
\hline Oper_9 & $\begin{array}{c}3.832 \\
(0.86) \\
\end{array}$ & $\begin{array}{c}-16.959 \\
(-3.52) \\
\end{array}$ & $\begin{array}{c}-19.008 \\
(-3.86) \\
\end{array}$ & $\begin{array}{c}-24.165 \\
(-4.42)\end{array}$ & $\begin{array}{c}-12.679 \\
(-4.06)\end{array}$ & $\begin{array}{c}-28.139 \\
(-4.40)\end{array}$ & $\begin{array}{c}-29.323 \\
(-4.86) \\
\end{array}$ \\
\hline Oper_10 & $\begin{array}{c}-10.974 \\
(-3.44)\end{array}$ & $\begin{array}{c}-12.532 \\
(-1.44)\end{array}$ & $\begin{array}{c}-14.820 \\
(-3.97)\end{array}$ & $\begin{array}{c}-19.860 \\
(-4.66)\end{array}$ & $\begin{array}{c}-12.158 \\
(-3.99)\end{array}$ & $\begin{array}{c}-12.060 \\
(-3.06)\end{array}$ & $\begin{array}{l}-28.990 \\
(-4.86)\end{array}$ \\
\hline Oper_11 & $\begin{array}{l}-29.602 \\
(-4.90)\end{array}$ & $\begin{array}{c}-18.236 \\
(-4.81)\end{array}$ & $\begin{array}{c}-8.112 \\
(-2.12) \\
\end{array}$ & $\begin{array}{r}-11.735 \\
(-3.82) \\
\end{array}$ & $\begin{array}{c}-12.332 \\
(-3.78) \\
\end{array}$ & $\begin{array}{c}-20.753 \\
(-4.73) \\
\end{array}$ & $\begin{array}{c}-20.704 \\
(-5.44)\end{array}$ \\
\hline Oper_12 & $\begin{array}{l}-27.457 \\
(-4.62) \\
\end{array}$ & $\begin{array}{r}-10.271 \\
(-3.42) \\
\end{array}$ & $\begin{array}{r}-20.315 \\
(-4.43) \\
\end{array}$ & $\begin{array}{c}-19.392 \\
(-4.60) \\
\end{array}$ & $\begin{array}{c}-19.921 \\
(-3.32)\end{array}$ & $\begin{array}{c}-12.358 \\
(-3.22)\end{array}$ & $\begin{array}{c}7.604 \\
(1.25) \\
\end{array}$ \\
\hline Oper_13 & $\begin{array}{c}-18.172 \\
(-4.66)\end{array}$ & $\begin{array}{c}-23.044 \\
(-3.88) \\
\end{array}$ & $\begin{array}{c}-26.395 \\
(-4.27) \\
\end{array}$ & $\begin{array}{c}-10.643 \\
(-3.74)\end{array}$ & $\begin{array}{c}-10.140 \\
(-2.75)\end{array}$ & $\begin{array}{c}-28.356 \\
(-4.56)\end{array}$ & $\begin{array}{c}-30.378 \\
(-5.03) \\
\end{array}$ \\
\hline Oper_14 & $\begin{array}{c}-22.479 \\
(-4.95) \\
\end{array}$ & $\begin{array}{c}-16.786 \\
(-4.38) \\
\end{array}$ & $\begin{array}{r}-9.439 \\
(-2.83) \\
\end{array}$ & $\begin{array}{c}-22.994 \\
(-4.34) \\
\end{array}$ & $\begin{array}{r}-12.631 \\
(-3.90) \\
\end{array}$ & $\begin{array}{c}-14.449 \\
(-3.98) \\
\end{array}$ & $\begin{array}{c}-18.242 \\
(-5.13) \\
\end{array}$ \\
\hline Oper_15 & $\begin{array}{c}-17.498 \\
(-4.88) \\
\end{array}$ & $\begin{array}{r}-20.109 \\
(-4.49) \\
\end{array}$ & $\begin{array}{c}-14.466 \\
(-3.79) \\
\end{array}$ & $\begin{array}{c}-20.213 \\
(-4.81) \\
\end{array}$ & $\begin{array}{r}-8.557 \\
(-2.32) \\
\end{array}$ & $\begin{array}{r}-14.907 \\
(-3.99) \\
\end{array}$ & $\begin{array}{r}-8.851 \\
(-2.71) \\
\end{array}$ \\
\hline Oper_16 & $\begin{array}{c}-29.611 \\
(-4.90) \\
\end{array}$ & $\begin{array}{r}-3.440 \\
(-1.09) \\
\end{array}$ & $\begin{array}{c}-28.000 \\
(-4.52)\end{array}$ & $\begin{array}{r}-20.197 \\
(-4.53) \\
\end{array}$ & $\begin{array}{c}-23.879 \\
(-4.31) \\
\end{array}$ & $\begin{array}{c}-23.291 \\
(-4.60) \\
\end{array}$ & $\begin{array}{c}-23.632 \\
(-3.13) \\
\end{array}$ \\
\hline $\operatorname{sigma}^{\star \star 2}$ & $\begin{array}{c}159.836 \\
(7.38) \\
\end{array}$ & $\begin{array}{r}169.321 \\
(8.12) \\
\end{array}$ & $\begin{array}{c}199.089 \\
(6.90) \\
\end{array}$ & $\begin{array}{r}148.029 \\
(7.12) \\
\end{array}$ & $\begin{array}{c}160.942 \\
(8.28) \\
\end{array}$ & $\begin{array}{c}200.423 \\
(7.56) \\
\end{array}$ & $\begin{array}{c}169322 \\
(7.30) \\
\end{array}$ \\
\hline $\begin{array}{l}\log \\
\text { likelihood }\end{array}$ & -955.13 & -1105.5 & -907.69 & -904.73 & 1159.1 & -98729 & -94226 \\
\hline $\mathbf{N}$ & 1911 & 1960 & 2009 & 1862 & 1862 & 1862 & 1960 \\
\hline
\end{tabular}


- The negative and significant coefficients of the short past absence variable may be due to the disciplinary policy that limits the total amount of absence that can be taken without having a significant effect on the employee's career in the agency.

- The winter and spring dummy variables are not significant (except the spring in area 132), suggesting that absence in these seasons is not significantly different from absence in the fall. However, the summer dummy variable is positive and significant in three out of the seven garages, suggesting that in these garages operators tend to be absent more in the summer.

\section{Conclusions}

These estimation results suggest that absence is best interpreted as a habit, operators differ in their absence rates, and those who tend to be absent do so independent of whether or not they recently worked overtime. If there is some relationship, then those who tend to work overtime tend to be absent less.

However, studies of absence are very complicated and the data that were available for this study do not resolve all of the potential problems. For example, although the researchers classified absences into several categories, it is difficult to classify every absence correctly as either voluntary or involuntary. The researchers are also missing many potentially important data in the model such as nonlabor income and personal and family characteristics, especially financial needs and responsibilities. In addition, many operators (particularly junior ones) will not have the option of working overtime. As runs are chosen according to seniority, junior operators are more exposed to stress than senior operators. Senior operators have overtime available, but they are not exposed to the same level of stress as junior operators. Another explanation might be that, because of the relatively high operator wage rate at the MBTA, the income effect is stronger than the substitution effect and employees can afford to buy more leisure time independent of the overtime premium.

If the hypothesis that absence is more a habit than the result of a decision process based on past overtime worked is accepted, then reducing overtime will not necessarily reduce absence, and the key to reducing absence is to develop a monitoring system that can identify employees who tend to be 
absent. However, further research is recommended in this area, which should be based on more extensive data and more agencies.

\section{References}

Brown, B. 1981. Building an operator availability program: San Francisco Municipal Railway. Paper presented at the Annual Meeting of the American Public Transit Association, Chicago, IL, October.

Buck, L., and S. Shimmin. 1959. Overtime and financial responsibility. Occupational Psychology 33:137-148.

Fichman, M. 1984. A theoretical approach to understanding employee absence. In P. S. Goodman and R. S. Atkin (Eds), Absence: New approach to understanding, measuring and managing employee absence.. San Francisco: Jossey-Bass, 158-193

Flanagan, R. J., G. Strauss, and L. Ulman. 1974. Worker discontent and workplace behavior. Industrial Relations 13:101-123.

Gowler, D. 1969. Determinants of the supply of labour to the firm. Journal of Management Studies 6:73-95.

Hickman, M. D., H. N. Koutsopoulos, and N. H. M. Wilson. 1988. Strategic model for operator workforce planning in the transit industry. Transportation Research Record 1165:60-68.

Koutsopoulos, H. N., and N. H. M. Wilson. 1987. Operator workforce planning in the transit industry. Transportation Research 21A, 2, 127-38.

Leahy, A., C. Sprague, and L. Schlegel. 1979. Bus operator absenteeism: Some causes and cures. Transit Journal Fall, 29-38.

Maddala, G. S. 1983. Limited dependent and qualitative variables in econometrics. Cambridge [Cambridgeshire]; New York: Cambridge University Press.

Martin, J. 1971. Some aspects of absence in a light engineering factory. Occupational Psychology 45:77-91.

Perin, C. 1984. The dynamics of vehicle operator absenteeism. Transportation Research Record 1002:1-7.

Perry, L. J. 1983. A study of extraboard scheduling, workers' compensation and operator stress in California public transit. Institute of Transportation Studies, University of California, Irvine.

Shiftan, Y., and N. H. M. Wilson. 1994. Absence, overtime and reliability relationships in transit workforce planning. Transportation Research, Part A, 28:245-258. 
Smith, J., D. L. Kiffe, and D. L. Lee. 1980. An approach to ideal manpower planning. Transit Journal Fall.

\section{About the Authors}

YoRam SHIFTAN (shiftan@tx.technion.ac.il) is a senior lecturer in the Department of Civil Engineering at the Technion, Israel Institute of Technology. His research and teaching are focused on travel behavior, demand modeling, transport economics, and transportation and air quality. Dr. Shiftan received his $\mathrm{Ph.D}$. in transportation systems from Massachusetts Institute of Technology and his master's degree in transportation engineering from the Technion. Prior to joining the Technion, Dr. Shiftan was a senior associate at Cambridge Systematics Inc.

Nigel Wilson (nhmw@mit.edu) is a professor of civil and environmental engineering at M.I.T. and the leader of the Engineering Systems Group, one of the three main organizational units in the Department of Civil and Environmental Engineering. His research and teaching are focused on urban public transportation, including topics related to the operation, analysis, planning, and management of transit systems. Prof. Wilson received his master's and doctoral degrees in civil engineering and transportation systems from M.I.T. 